\title{
A kórházi étrend hazai helyzete és a tápszeres kiegészítés jelentösége a betegellátásban
}

\author{
The situation of the Hungarian hospital diet and \\ the importance of the dietary supplements in the medical attendance
}

Nagy Nóra Zsófia1, Dr. Molnár Szilvia², Veresné Dr. Bálint Márta²

1 Szent Imre Egyetemi Oktatókórház, Semmelweis Egyetem, Egészségtudományi Doktori

Iskola, ${ }^{2}$ Semmelweis Egyetem, Egészségtudományi Kar, Dietetikai és Táplálkozástudományi Tanszék

Az energiatartalomban megfelelö, a tápanyagokat kiegyensúlyozott arányban tartalmazó kórházi étrend a betegségek terápiájának fontos eleme. Cikkünkben a kórházi étrend szerepét és jelenlegi hazai helyzetét vizsgáljuk a terápia hatékonyságának és a betegellátás színvonalának növelése érdekében. Módszer: nemzetközi kutatások eredményeinek és javaslatainak a hazai helyzethez való viszonyítása, figyelembe véve a jogszabályban lefektetett elöírásokat és a gyakorlat tapasztalatait. Megállapítások: bizonyos helyzetek (pl. magas malnutríció rizikó, módosított textúrájú diéták) gyakrabban járnak együtt elégtelen energia- és tápanyagbevitellel, így fokozott figyelmet kell fordítani a dieto- és táplálásterápia megtervezésére. Amennyiben a fekvőbeteg-ellátási intézmények diétája nem tudja biztosítani a beteg rehabilitációjához szükséges létfontosságú tápanyagokat, úgy az étrendet gyógyászati célra szánt tápszerrel, tápszerekkel kell kiegészíteni. A betegélelmezés szubjektív és objektív megítélése javítható a szakmában jártas törvény- és döntéshozók egészség- és táplálkozáspolitika iránti elkötelezettségével (jogszabályi háttér részletesebb kidolgozása és a kórházi étkezésre fordítható minimum napi norma emelése), és a dietetikusok individuális betegellátásba való hathatósabb bevonásával.

A well-planned hospital diet (adequate energy, micro and macro nutrient content) is one of the most important elements of the therapy. The present article analyses the role and situation of the diets used in Hungarian hospitals in order to improve the success of recovery and the level of medical attendance. Method: to compare the results and suggestions of international research to the Hungarian situation considering regulation and experiences from the practice. Conclusion: in some cases, (e.g.: high malnutrition risk, texture modified diets) a lower energy and nutrition input is more common, so we need to give more attention to plan the dieto- and nutrition therapy. If a hospital diet is not able to ensure the nutrients for the successful recovery, the use of dietary supplements is crucial. To improve subjective and objective opinions of the patient catering, there is a need for the commitment of the Hungarian legislative bodies and decision makers (detailed revision of the regulation, rising up of the daily fee for the patient catering) and the dietitians' active participation in the individual hospital patient care.

\section{BEVEZETÉS}

Már az ókori görögöknél megtalálhatóak voltak a mai értelembe vett diéták korai változatai, amelyek az egészséges életmódhoz és a betegségek kezeléséhez adtak iránymutatást. A Corpus Hippocraticum egy Krisztus előtti ötödik és kora negyedik századból származó ókori görög gyűjtemény, amely a Hippokratészi tanításokat őrzi. Köszönhetően ezen feljegyzéseknek, az akkori táplálkozási javaslatokról, a „diaita"-ról is képet kaphatunk [1]. A mai orvostudomány olyan ismeretek birtokában van, amelyet az akkori emberek elképzelni sem tudtak. A táplálkozási irányelvek szintén sokat változtak, napjainkban a táplálkozástudomány egy biztos lábakon álló, ám még mindig megújulni képes tudomány. A dietetika terápiás ereje és a dietetikusnak a betegedukációban betöltött szerepe megkérdőjelezhetetlen, fontos tényezővé vált. A hazai lakosság táplálkozási szokásai számos, nem fertőző betegség gyakoribb előfordulásához járulnak hozzá $[2,3]$. Amennyiben a prevenció nagyobb teret kapna, kevesebb teher esne a kórházakra, amelyek így a dietetoterápia oktatásának kulcsfontosságú helyszíneiként is funkcionálnak. Tekintve, hogy a dietoterápia oktatásának egyik módszere az - elsősorban alapvető szükségleteket kielégítő - betegélelmezés, cikkünkben a hazai helyzetet mutatjuk be, előremutató megoldásokat javasolva.

\section{KÓRHÁZ MINT TERÁPIÁS HELYSZÍN}

A kórház nem csupán fekvőbeteg-ellátást biztosít a betegek számára, hanem a szakrendelőkön /ambulanciákon keresztül a járóbeteg-gondozás helyszíne is. Ez utóbbi esetén az intézmény nem köteles étkezést biztosítani a betegeknek, de amint indokolttá válik az osztályra való felvétel, az élelmezésről is gondoskodnia kell. Magyarországon jelenleg még nincs külön jogszabály a fekvőbeteg-ellátási intézmények betegélelmezésére vonatkozóan. Az óvodákhoz, iskolákhoz, idősotthonokhoz hasonlóan, a kórházakra is a $37 / 2014$ (IV.30.) közétkeztetési EMMI rendelet utasításai az iránya- 
dóak. Habár a rendelet bizonyos bekezdései kitérnek a fekvőbeteg-ellátási intézmények diétás étrendjére - valamint az útmutató későbbi módosítása igyekezett az egészségesek és a diétát igénylők szükségletei közötti különbségeket megfelelő szabályozási keretek közé terelni - a gyakorlatban még mindig merülnek fel kérdések, problémák [4,5]. Ez abból is adódik, hogy a különböző diéták alappillérei jelentős különbségeket mutatnak (például energia-, fehérje-, zsír- vagy rostbevitellel, füszerezéssel kapcsolatos jellemzők), így a minimum elvárt változatossági mutatónak is megfelelő összehangolt szabályozás nem egyszerű feladat. Az intézmények igen szűk mozgástérrel rendelkeznek az anyagiak terén is, hiszen a napi kórházi élelmezési normát 2007-ben, az akkori egészségügyi miniszter emelte - a jelenleg is érvényben lévő átlagos forgalmi adó nélküli, betegenként minimum 550 forintra [6]. Komoly kérdéseket feszegető problémák ezek, amelyek nemcsak az ételek mennyiségi és minőségi jellemzőit, az élelmezés változatossági mutatóját - ezáltal a betegek élelmezésről alkotott pozitív megítélését - veszélyeztetik, hanem akár egyes diéták alapelveinek megsértésével is járhatnak. Az emberi és tárgyi feltételek hiányosságai mellett leginkább az elmúlt 14 év „normaemelési mozdulatlansága” alakította úgy a helyzetet, hogy a kórházi élelmezésről országos szinten negatív kép alakuljon ki. Egy kifejezetten a betegellátási intézményekre szabott, részletesen kidolgozott élelmezési jogszabály talán jobban körül tudná határolni a különböző betegségek és állapotok miatt diétát tartók objektív igényeit (például ajánlott energia- és tápanyagbevitel, megfelelő változatossági mutató), az étkeztetésre fordítható, napi kórházi norma emelkedése pedig a szabályozás gyakorlati megvalósításában segítene. Ha mindezek mellett a beteg szubjektív igényei is kielégülnek (például az ételek megfelelő hőmérséklete, laktatóértéke vagy íze), az a betegélelmezés megítélésén is jelentősen javítana.

\section{INDIVIDUALITÁS KÉRDÉSE}

Egy jól felépített betegélelmezési rendszerben az individualitás is nagyobb hangsúlyt kap (a fent említett objektív igények biztosítása mellett), mivel az egyéni jellemzők is alakítják a beteg dietoterápiájának alapjait. Az individualitás tehát a rehabilitáció és a gyógyulás sikerességét segíti elő, ami a fekvőbeteg-ellátási intézmények legfőbb célja. A kórházban dolgozó dietetikus feladata a betegágy és/vagy az ambulancián történő egyéni vagy csoportos dietetikai tanácsadás, a táplálásterápiás terv készítése és ezek dokumentálása. Ha a dietetikus által javasolt mennyiségre és minőségre vonatkozó kritériumok sérülnek, a beteg számára nem lesz megfelelően biztosított az egyénre szabott étrend, amely aztán hatással lesz a betegsége kimenetelére és a gyógyulás sikerességére. Ha a kórházban nincs megoldva az egyéni tálcás tálalás (legmodernebb, legindividuálisabb étkeztetési forma), ha nem elég részletes az élelmezési diétákat tartalmazó lista, amelybe a beteg éppen aktuális terápiás étrendje beilleszthető, ha bizonyos ételek nem elkészíthetőek az adott intézmény élelmezési üzemében (hiányos konyhai dolgozói lét- szám, rossz tárgyi feltételek), akkor mindezek következtében szubjektíven és a rendelet előírásainak megfeleltetve objektíven is egy kevésbé változatosra minősített étlap foroghat újra és újra. Az individualitás sérül, ha dietetikus egyáltalán nem dolgozik az élelmezésen (annak ellenére, hogy kórházi körülmények között az élelmezésvezetőnek kötelező dietetikus végzettséggel rendelkeznie), és emiatt a szakmai felügyelet nincs biztosítva [4]. Örök igazság, hogy az a diéta használ, amit a beteg el is fogyaszt, így habár a betegek ízpreferenciája rendkívül szubjektív tényező, az élelmezési ellátás során törekedni kell az ízletesség elérésére, a tálalás étvágy-elősegítő módjára. Individualitás szempontjából fontos tényező a beteget ellátó személyzet jelenléte is. Nyelési zavaros betegek esetében szignifikánsan magasabb energiabevitelt jelentett a betegágy melletti, célzott asszisztencia. Azoknál a betegeknél, akiknél egy megbízott személy a kórházi ételekhez kedvet hozott, az étkezésben segédkezett, illetve a tápszert naponta többször kínálta, átlagot nézve az energiaszükséglet 80,4\%-a biztosítva lett (szemben az asszisztencia nélküli kontroll csoporttal, ahol átlagosan a szükséglet csupán 41,6\%-a lett fedezve). Tekintettel a szignifikáns különbségre, Wright és munkatársai az önkéntesek bevonását javasolják arra az esetre, ha az ápoló személyzet kapacitása nem teszi lehetővé az ilyen mértékű betegágy melletti jelenlétet [7]. Ismerve a hazai egészségügyben dolgozók létszámát és a leterheltség mértékét, kérdés, milyen módon lehetne a malnutríció szempontjából közepes vagy magas kockázatú betegeket - a kutatáshoz hasonló módon - asszisztenciában részesíteni. Talán a hazai viszonylatban is az önkéntesek bevonása jelentené a megoldást.

\section{FOKOZOTT FIGYELMET IGÉNYLŐ DIÉTÁK, HELYZETEK}

A betegélelmezés gyakorlatában megfigyelhető, hogy bizonyos kórházi diéták kisebb beltartalmi értékkel rendelkeznek a normál étrendhez vagy más diétákhoz képest. Az alacsonyabb energia- és tápanyagtartalmú diétán lévő betegek fokozottan kitettek a malnutrícióra, így az alultápláltság szűrése, a táplálásterápiás terv kidolgozása és alkalmazása, illetve a monitorozás a betegellátás fontos eleme. Kutatások is alátámasztják, hogy a normál konzisztenciától eltérő, pépesített, puding állagú ételekből álló diéták fokozott figyelmet igényelnek. A diszfágiások számára biztosított módosított textúrájú diéták szignifikánsan alacsonyabb energia- és fehérjetartalommal rendelkeznek a normál konzisztenciájú diétákhoz képest. Ezzel a diétával kapcsolatban csak a 2000-es években kezdtek el kutatásokat folytatni. Úttörő kutatásnak számít Wright és munkatársai cikke, ahol a kórházi körülmények között vizsgált, nyelési zavaros idős betegeknél azt találták, hogy a módosított textúrájú diéta átlagosan csupán 926 kcal energia- és $40 \mathrm{~g}$ fehérjebevitelt jelentett. Az alacsony energia- és tápanyagbevitelt az evés nehezítettségével, a szegényes ételválasztékkal, a kevésbé ízletes ételekkel, valamint a tálalási körülmények együttes jelenlétével magyarázták. A vizsgálatba bevont betegek csupán 13\%-a fogyasz- 
totta el a felkínált ételeket és a csoport 93\%-ának fehérjebevitele nem érte el az élettanilag szükséges mennyiséget. Következtetésképpen a cikk szerzői szükségesnek vélik a tápszeres kiegészítés rutinszerű alkalmazását minden diszfágiás betegnél [8]. Egy japán kutatás is hasonló eredményre jutott, a diszfágiások átlagosan 956,8 kcal és 33,1g fehérjét vittek be a módosított textúrájú diétával. Feltételezhetően ez is hozzájárult ahhoz, hogy a csoport több mint felénél alultápláltságot diagnosztizáltak [9]. A pépesített vagy pürésített étrendek a fekvőbeteg-ellátási intézmények bármely osztályán szükségessé válhatnak, ha a betegnek rágási-, nyelési nehezítettsége van, ha bizonyos mütét után - átmenetileg pépesített diétát írtak elő, illetve, ha a demencia súlyossága miatt az étkezésben az ápoló személyzetnek is segédkeznie kell (geriátriai vagy krónikus, ápolási osztályok). Normál konzisztencia esetén fokozott figyelemmel kell eljárni azokban az esetekben is, amikor közepes vagy magas malnutríció rizikójú beteget kell ellátni. Pontozási rendszeres tesztekkel felmérhető ennek mértéke az alábbi tényezőket figyelembe véve: a beteg egy ideje étvágytalan, az elmúlt 3 hónapban fogyott és/vagy a testtömeg indexe (BMI) alacsony, vagy életkora kockázati tényezőnek számít [10]. Tekintve, hogy a gyakorlati tapasztalatokat a kutatások is alátámasztják, az energia- és tápanyagbevitelt növelő tápszeres kiegészítés alkalmazása, sok esetben szükségszerűvé vált, rutinszerűen alkalmazandó.

\section{ÖSSZEFÜGGÉSEK, A TÁPSZERES KIEGÉSZíTÉS LEHETŐSÉGEI}

A fent megfogalmazottak alapján kiderül, hogy bizonyos esetekben az élelmezés által biztosított energia- és tápanyagbevitel nem fedezi a beteg rehabilitációjához szükséges mennyiséget, a tápszeres (hivatalos nevén speciális gyógyászati célra szánt élelmiszer) kiegészítés indokolt. A tápszeres kiegészítés fontosságára több, nagy esetszámú kutatás felhívja a figyelmet. A kórházi étrend melletti orális energia- és fehérjebeviteli kiegészítés, a kórházban töltött napok számának csökkenése mellett a mortalitás csökkenését is eredményezte [11,12,13]. Egy 2015 és 2019 közötti metaanalízis rámutatott a kizárólag kórházi, előírt diétán lévő betegek és a diéta mellett tápszeres kiegészítésben is részesülők betegség prognózisbeli különbözőségére: a tápszeres kiegészítés 53\%-kal csökkentette a halálozás kockázatát. A szerzők minden kórházba került malnutríciós beteg esetében szükségszerūnek tartják a tápszeres kiegészítés rutinszerü alkalmazását [14]. Annak ellenére, hogy a tápszeres kiegészítés sok esetben indokolt, a gyakorlatban nem mindig valósul meg. Az energia- és tápanyagbevitel szempontjából különös figyelmet igénylő diszfágiás betegek esetében azt talál- ták, hogy csupán felüknél (54\%) volt tápszeres kiegészítés előírva, illetve csupán 37\% fogyasztotta el ténylegesen azt [8]. Hazai viszonylatban hasonló arány körvonalazódik PhD kutatási eredményeim alapján (kórházban, kifejezetten a diszfágiások körében végzett vizsgálat), de nagyobb esetszám és pontos statisztikai módszerekkel kapott eredmények szükségesek a tudományos színvonal eléréséhez [15]. A táplálásterápiás terv megtervezése dietetikusi kompetencia. $A z$ ideális tápszer megválasztása és a fogyasztási mennyiség meghatározása miatt a dietetikus a beteget ellátó team elengedhetetlen tagja. Fontos, hogy a team többi tagja is tudatában legyen annak, hogy a tápszeres kiegészítés alkalmazása bizonyos esetekben nem elkerülhető. Ideális, ha a tápszerekre külön - például intézményi - keret nyílik, ezáltal nem az osztályok gyógyszerkerete terhelődik, tehát nem kell két, terápia sikerességéhez hozzájáruló tényező közül választani. Az ápoló személyzet betegágy melletti jelenlétének fontosságát pedig az is alátámasztja, hogy az elfogyasztott étel mennyisége mellett a tápszerbevitel mértéke is jelentősen nőtt az egyéni asszisztenciának köszönhetően [7].

\section{KÖVETKEZTETÉSEK, A POZITÍV JÖVŐKÉP LEHETŐSÉGEI}

Gondolatébresztő cikkünkkel a kórházi élelmezés minőségének fontosságára, a jelenlegi helyzet komplexitására és bizonyos problémákra szerettünk volna rámutatni. Véleményünk szerint a betegeknek már a kórházban eltöltött idő alatt tapasztalniuk kell a dietetikai tanácsadás során átadott diéta jellemzőket: a diétába beilleszthető nyersanyagok lehető legszélesebb választékát, a javasolt ételkészítési eljárásokat, a változatosságot, a megfelelő ízélményt és az étvágyat elősegítő tálalási módot. A kórházi diéták minőségi és mennyiségi megítélésének javításához elengedhetetlen a szakmában jártas törvény- és döntéshozók egészség- és táplálkozáspolitika iránti elkötelezettsége, a valóságban a betegélelmezés pontosabb jogi szabályozása és ellenőrzése, a kórházi étkezésre fordítható minimum norma emelése, valamint a dietetikusok hathatósabb bevonása az individuális betegellátás biztosításába. A diéták terápiás szerepét a kezdet (ókori) tapasztalatok után, most már számos kutatási eredmény alátámasztja. Amennyiben a kórházi ellátás keretein belül ennek megvalósítása akadályoztatva van, a beteg egészséghez való joga sérül. Érdemes lenne minden intézményben - a helyi adottságokhoz alkalmazkodva - protokoll szintre emelni a tápszerekkel való kiegészítés menetét, a dietetikusi konzultáció fontosságát, hiszen egy jól felépített táplálási terv és ennek monitorozása kulcsfontosságú tényező a rehabilitáció során.
[1] Loine IM: A structural pattern in Greek dietetics and the early history of Greek medicine. Medical History. 21(3): 235-260. https://doi.org/10.1017/S0025727300038242
[2] Sarkadi Nagy E, Bakacs M, Illés É, és mtsai.: Országos Táplálkozás és Tápláltsági Állapot Vizsgálat - OTÁP 2014. II. A magyar lakosság energia és makrotápanyag 
bevitele. Orvosi Hetilap. 2017; 158(15): 587-597

https://doi.org/10.1556/650.2017.30718

[3] Nagy B, Nagy-Lőrincz Zs, Bakacs M, és mtsai.: Országos Táplálkozás és Tápláltsági Állapot Vizsgálat OTÁP2014. III. A magyar lakosság makroelem-bevitele. Orvosi Hetilap. 2017; 158(17): 653-661. https://doi.org/10.1556/650.2017.30744

[4] 37/2014. (IV. 30.) EMMI rendelet a közétkeztetésre vonatkozó táplálkozás-egészségügyi előírásokról. http://njt.hu/cgi_bin/njt_doc.cgi?docid=169011.361140 (Megtekintve: 2021.08.25.)

[5] 36/2016. (XII. 8.) EMMI rendelet a közétkeztetésre vonatkozó táplálkozás-egészségügyi előírásokról szóló 37/2014. (IV. 30.) EMMI rendelet módosításáról. http://njt.hu/cgi_bin/njt_doc.cgi?docid=199083.331021 (Megtekintve: 2021.08.25.)

[6] 43/1999. (III.3.) Korm. rendelet. 45/A. § Az egészségügyi szolgáltatások Egészségbiztosítási Alapból történő finanszírozásának részletes szabályairól. https://net.jogtar.hu/ jogszabaly?docid=99900043.kor (Megtekintve: 2021.08. 25.)

[7] Wright L, Cotter D, Hickson M: The effectiveness of targeted feeding assistance to improve the nutritional intake of elderly dysphagic patients in hospital. Journal of Human Nutrition and Dietetics, 2008, 21, 555-562. https://doi.org/10.1111/j.1365-277X.2008.00915.x

[8] Wright L, Cotter D, Hickson M and Frost G: Comparison of energy and protein intakes of older people consuming a texture modified diet with a normal hospital diet. Journal of Human Nutrition and Dietetics, 2005, 18(3), 213-219. https://doi.org/10.1111/j.1365-277X.2005.00605.x
[9] Shimizu A, Maeda K, Tanaka K et al.: Texture-modified diets are associated with decreased muscle mass in older adults admitted to a rehabilitation ward. Geriatrics \& Gerontology International, 2018, 18, 698-704. https://doi.org/10.1111/ggi.13233

[10] Kondrup J, Allison SP, Elia M et al.: ESPEN guidelines for nutrition screening 2002. Clinical Nutrition, 2003 , 22(4), 415-421. https://doi.org/10.1016/S0261-5614(03)00098-0

[11] Kaegi-Braun N, Mueller M, Schuetz P, et al.: Evaluation of nutritional support and in-hospital mortality in patients with malnutrition. JAMA Network Open, 2021, 4(1): e2033433.

https://doi.org/10.1001/jamanetworkopen.2020.33433

[12] Schuetz P, Fehr R, Baechli V et al.: Individualised nutritional support in medical inpatients at nutritional risk: a randomised clinical trial. Lancet, 2019, 393: 2312-21 doi: https://doi.org/10.1016/S0140-6736(18)32776-4

[13] Deutz ED, Matheson EM, Matarese LE et al.: Readmission and mortality in malnourished, older, hospitalized adults treated with a specialized oral nutritional supplement: A randomized clinical trial. Clinical Nutriton, 2016, 35, 18-26. https://doi.org/10.1016/j.clnu.2015.12.010

[14] Gomes F, Baumgartner A, Bounoure L et al.: Association of nutritional support with clinical outcomes among medical inpatients who are malnourished or at nutritional risk. An updated systematic review and meta-analysis. JAMA Network Open. 2019, 2(11):e1915138. https://doi.org/10.1001/jamanetworkopen.2019.15138

[15] Nagy NZs: A stroke dietoterápiájának nehézségei a kórházi ellátásban. Ideggyógyászati Szemle Proceedings/ Clinical Neuroscience Proceedings, 2019, 4 (1), 61

\section{A SZERZŐK BEMUTATÁSA}

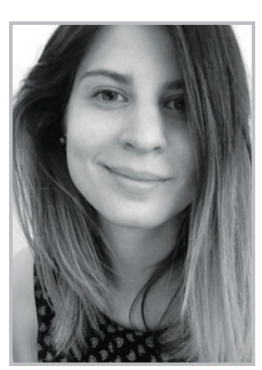

Nagy Nóra Zsófia 2013-ban végzett a Semmelweis Egyetem Egészségtudományi Karán dietetikusként. Azóta a Szent Imre Egyetemi Oktatókórház Dietetikai Szolgálatánál tevékenykedik, terápiás dietetikusként. 2019-ben szerzett Táplálkozástudományi MSc diplomát és lett a Semmelweis Egyetem

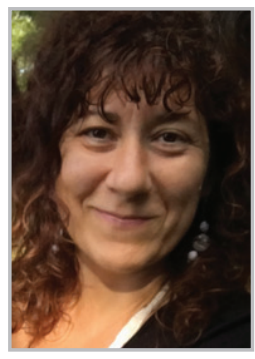

Dr. Molnár Szilvia PhD, dietetikus, okleveles élelmiszermérnök és okleveles mérnöktanár. Diplomáit a Haynal Imre Egészségtudományi Egyetem Egészségügyi Főiskolai Kar dietetika szakán (2002), a Budapesti Corvinus Egyetem Társadalomtudományi Kar mérnöktanári szakán (2007) és az Élelmiszertudományi Kar élelmiszeripari mene-
Doktori Iskolájának hallgatója. Kutatási témája a diszfágia dieto- és táplálásterápiája. Jelenleg a Semmelweis Egyetem Egészségtudományi Kar, Dietetikai és Táplálkozástudományi Tanszékének oktatója, illetve a végzős dietetikus hallgatók kórházi gyakorlatvezetője, a gyakorlati államvizsga bizottságának tagja. Kórházi munkáját a betegközpontú hozzáállás jellemzi.

PhD értekezését, fő kutatási területe a közétkeztetés és a táplálkozási magatartásnevelés. 2000-től tagja a Magyar Dietetikusok Országos Szövetségének (MDOSZ), 2001-től a Magyar Táplálkozástudományi Társaságnak.

2002-től 2010-ig élelmezési osztályvezető helyettesként dolgozott az Országos Orvosi Rehabilitációs Intézetben Budapesten. Jelenleg a Semmelweis Egyetem Egészségtudományi Kar Alkalmazott Egészségtudományi Intézet Dietetikai és Táplálkozástudományi Tanszékén adjunktusként oktat. 


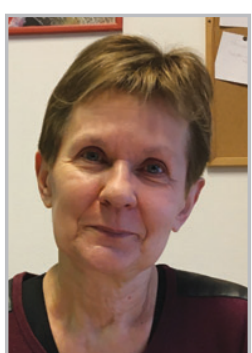

Veresné Dr. Bálint Márta dietetikus, okleveles élelmiszer minőségbiztosító agrármérnök, az egészségtudományok doktora. Pályáját dietetikusként kezdte a Pest Megyei Flór Ferenc Kórházban, majd 35 évvel ezelőtt bekapcsolódott a dietetikusok képzésbe, jelenleg a Semmelweis Egyetem Egészségtudományi Kar Dietetikai és Táplálkozástudományi Tanszék tanszékvezető főiskolai tanára. Hazai és külföldi szakmai konferenciák rendszeres előadója, pályázatok résztvevője, és közremüködik szakmai irányelvek fejlesztésében, véleményezésében. Szakmai publikációi mellett fontosnak érzi az egészségnevelést, tudományos ismeretterjesztést is. Szakterülete a gyakorlati dietetika, ezen belül az időskori táplálkozás, a nefrológiai, és a kardiovaszkuláris betegségek dietetikája. Folyamatosan részt vesz a dietetikus (BSc) és a táplálkozástudományi (MSc) képzés tantervének, tananyagának fejlesztésében. Szakértőként dolgozik a Magyar Akkreditációs Bizottságban.

\section{Január 5-éig várják a jelöléseket az Érték Vagy! elismerésre}

Egy hónapig, vagyis január 5-éig várják a jelöléseket az Érték Vagy! díjra, amely a megváltozott munkaképességüek foglalkoztatásának fontosságára irányítja a figyelmet - közölte az Emberi Erőforrások Minisztériumának szociális ügyekért felelős államtitkára hétfőn Kecskeméten.

Fülöp Attila a kecskeméti postán tartott sajtótájékoztatón elmondta: a kormány olyan gazdasági növekedésért dolgozik, amelynek lehetőség szerint mindenki a haszonélvezője lehet.

Hangsúlyozta, hogy a magyar gazdaságban az elmúlt tíz évben mintegy egymillióval nőtt a foglalkoztattak száma. Ezen belül a legnagyobb arányban a legnehezebb munkaerőpiaci helyzetben lévő, megváltozott munkaképességűek foglalkoztatása bővült, hiszen ezen időszak alatt 150 százalékkal nőtt.

Az államtitkár kiemelte: a jövőben tovább szeretnék erősíteni ezt a foglalkoztatási formát, mivel a megváltozott munkaképességű emberek foglalkoztatásának bővítése „egyrészt gazdasági potenciál, másrészt leszámolás a kontraproduktív baloldali segélyezéspolitikával, harmadrészt pedig közösségteremtő felelősségvállalást is jelent” - fogalmazott.

Fülöp Attila emlékeztetett, a 2020-ban elindított Érték Vagy! programmal a megváltozott munkaképességűek és a fogyatékossággal élők értékeire hívják fel a figyelmet, valamint elismerést is létrehoztak a foglalkoztatásukért végzett kiemelkedő tevékenység díjazására.

A díjra elsősorban olyan munkáltatók vagy magánszemélyek jelölését várják, akik segítették megváltozott munkaképességű honfitársaikat például az elhelyezkedésben, foglalkoztatóként kiváló példát mutatnak, vagy magánszemélyként sokat tettek az ügyükért - sorolta a politikus.

A jelölés folyamata megtalálható a https://www.ertekvagykonferencia.hu/ oldalon, a díjat a járványhelyzettől függően a január 27-ére tervezett Érték Vagy! nemzetközi konferencia keretében adják majd át.

Fülöp Attila szerint azért is fontos ez az elismerés, hogy „a megváltozott munkaképességű emberek foglalkoztatásának ne csak a gazdasági, de a szolidaritási részét is előtérbe lehessen helyezni”.

A sajtótájékoztató helyszínéül azért választották a kecskeméti postát, mert a Magyar Posta Zrt. egy olyan intézmény, amelyet minden magyar állampolgár ismer - mondta az államtitkár. Hozzátette: „a megváltozott munkaképességűek foglalkoztatása is olyan ügy, amelyet minden magyar állampolgár ismer, még ha nem is beszél róla minden nap".

Schamschula György, a Magyar Posta Zrt. vezérigazgatója kiemelte: a második legnagyobb hazai foglalkoztatóként társadalmi felelősségnek érzik, hogy vállalatuk minél több megváltozott munkaképességű embernek biztosítson megélhetést. Beszámolt arról is, hogy arányuk növelése érdekében indították el a Tegyünk együtt! programot, valamint ősszel stratégiai megállapodást kötöttek az Emberi Erőforrások Minisztériumával is.

A posta 27 ezer munkavállalójából jelenleg 200 valamilyen fogyatékossággal élő, közülük a kecskeméti Kálvin téri postán hárman dolgoznak, így van már tapasztalatuk a megváltozott képességű emberek befogadásában és megtartásában - fogalmazott a vezérigazgató.

Engert Jakabné, Kecskemét alpolgármestere elmondta: az önkormányzat elkötelezett a megváltozott munkaképességűek foglalkoztatása iránt, évi közel hatvanmillió forint támogatást nyújt annak érdekében, hogy több civil szervezet és munkáltató biztosítson munkát mintegy hetven fogyatékossággal élő számára. 